\title{
Leaching of fluridone, hexazinone and simazine in sandy soils in the Netherlands
}

\section{R. ZANDVOORT}

Centre for Agrobiological Research, P.O. Box 14, 6700 AA Wageningen, Netherlands

Received 22 February 1989; accepted 6 July 1989

\begin{abstract}
Fluridone and simazine were sprayed in field experiments on coarse and humic sandy soils in spring or in late autumn, and hexazinone on coarse sand in spring. After a spring application, over an eight-month period, fluridone and hexazinone were detected by bio-assay in the profile of coarse sand from 0 to $60 \mathrm{~cm}$, whereas simazine did not leach below $15 \mathrm{~cm}$. Both fluridone and simazine were found to a depth of $60 \mathrm{~cm}$ in coarse sand after an application in late autumn. Thus, at winter conditions the transformation rate is not fast enough to prevent leaching of fluridone and simazine to deeper soil layers after autumn application.
\end{abstract}

Keywords: leaching, herbicide, fluridone, hexazinone, simazine

\section{Introduction}

On sandy soils with a very low organic matter content, adsorption of herbicides might be too low to prevent leaching and subsequent contamination of ground water. This may be illustrated with results obtained by Zandvoort et al. (1980), who found that in a sand bed of a railway track with a low content of organic matter, bromacil penetrated to depths around $100 \mathrm{~cm}$.

Since bromacil can contaminate ground water, we began looking for alternatives. Fluridone and hexazinone were chosen for testing because of their different solubility in water and their spectrum of weed control. Simazine was included as a reference substance.

Leaching will be favoured by weak adsorption and by conditions which retard degradation. Fluridone is adsorbed strongly to organic matter and will only partly desorb (Weber et al., 1986). Adsorption of simazine correlated very positively with organic matter content (Talbert \& Fletchall, 1965). Despite repeated washings, $10 \%$ of simazine was not released. Rhodes (1980) and Bouchard \& Lavy (1985) found a weak adsorption of hexazinone in loamy soils. Fluridone has a long persistence and is degraded by micro-organisms (Banks et al., 1979). Degradation is retarded by lowering the temperature, as has been found for simazine (Walker, 1976) and hex- 


\section{R. ZANDVOORT}

azinone (Bouchard et al., 1985); and by lowering the soil moisture content, as has been found for simazine (Walker, 1976).

From the available data on sorption and transformation of fluridone and hexazinone, leaching of these herbicides from railway beds cannot be excluded. Therefore in the present study their leaching from coarse sandy soils was studied under field conditions. A few experiments were done on a normal agricultural soil.

\section{Materials and methods}

Field experiments on coarse sand beds of a railway track were laid out near Maarn in 1980 and Elst (Gelderland) in 1981/1982. The experiment on humic sand was situated on an agricultural field near Wageningen in 1981. Organic matter content in the $0-10 \mathrm{~cm}$ layers of soil was $2.4,1.0$ and $2.0 \%$, clay content 3,2 and $6 \%$, and the moisture content at field capacity $11,5.5$ and $15.5 \%$ for the Maarn, Elst and Wageningen soils, respectively.

The sites were divided into four blocks with randomized treatments and kept free from vegetation. Commercial wettable powder formulations were applied in coarse droplets in 600 litres of water per hectare from a propane knapsack sprayer.

Fluridone and simazine were sprayed in spring at Maarn in dosis of $2.5 \mathrm{~kg} \mathrm{ha}^{-1}$, at Elst in doses of 2 and $4 \mathrm{~kg} \mathrm{ha}^{-1}$, respectively, and at Wageningen in doses of 2 $\mathrm{kg} \mathrm{ha}^{-1}$. At Elst, simazine and fluridone were sprayed in doses of $2 \mathrm{~kg} \mathrm{ha}^{-1}$ in autumn. Hexazinone was sprayed at Elst in spring in a doses of $3 \mathrm{~kg} \mathrm{ha}^{-1}$.

Soil samples for residue analysis by bio-assays were collected as described by Zandvoort et al. (1980).

Simazine in soil samples from Maarn and Wageningen was detected by bio-assay using a nutrient solution with fodder radish (Raphanus sativus L. spp. oleiferus (DC.) Metzg.) cv. Siletina (Zandvoort \& Braber, 1981). Residues of fluridone were detected with oat plants (Avena sativa L. cv. Condor) grown in the samples as described by Zandvoort et al. (1979). Simazine and hexazinone in the Elst soil was detected in the same way. The plants were exposed to the nutrient solution or to the soil samples during 3 or 4 weeks. The detection limit of fluridone and hexazinone was $0.02 \mathrm{mg}$ per $\mathrm{kg}$ dry soil and of simazine $0.07 \mathrm{mg}$ per $\mathrm{kg}$ dry soil. In some samples with levels of fluridone below the detection limit, symptoms (retardation of growth and chlorosis in combination with a transverse constriction in the middle of the leaves) typical of its presence were observed in the test plants.

\section{Results}

After an application in spring (Fig. 1), residues of fluridone and simazine in humic sand at Wageningen were found mainly in the layer $0-5 \mathrm{~cm}$, especially the upper 2 $\mathrm{cm}$. The concentration decreased below the detection limit at a depth of $10 \mathrm{~cm}$. For fluridone, $15 \%$ of the total applied mass was recovered after 4 months, and for simazine $20 \%$ after 5 months.

Fluridone and simazine residues in coarse sand samples from Elst and Maarn were found mainly in the top $10 \mathrm{~cm}$. Only small quantities of these herbicides were 

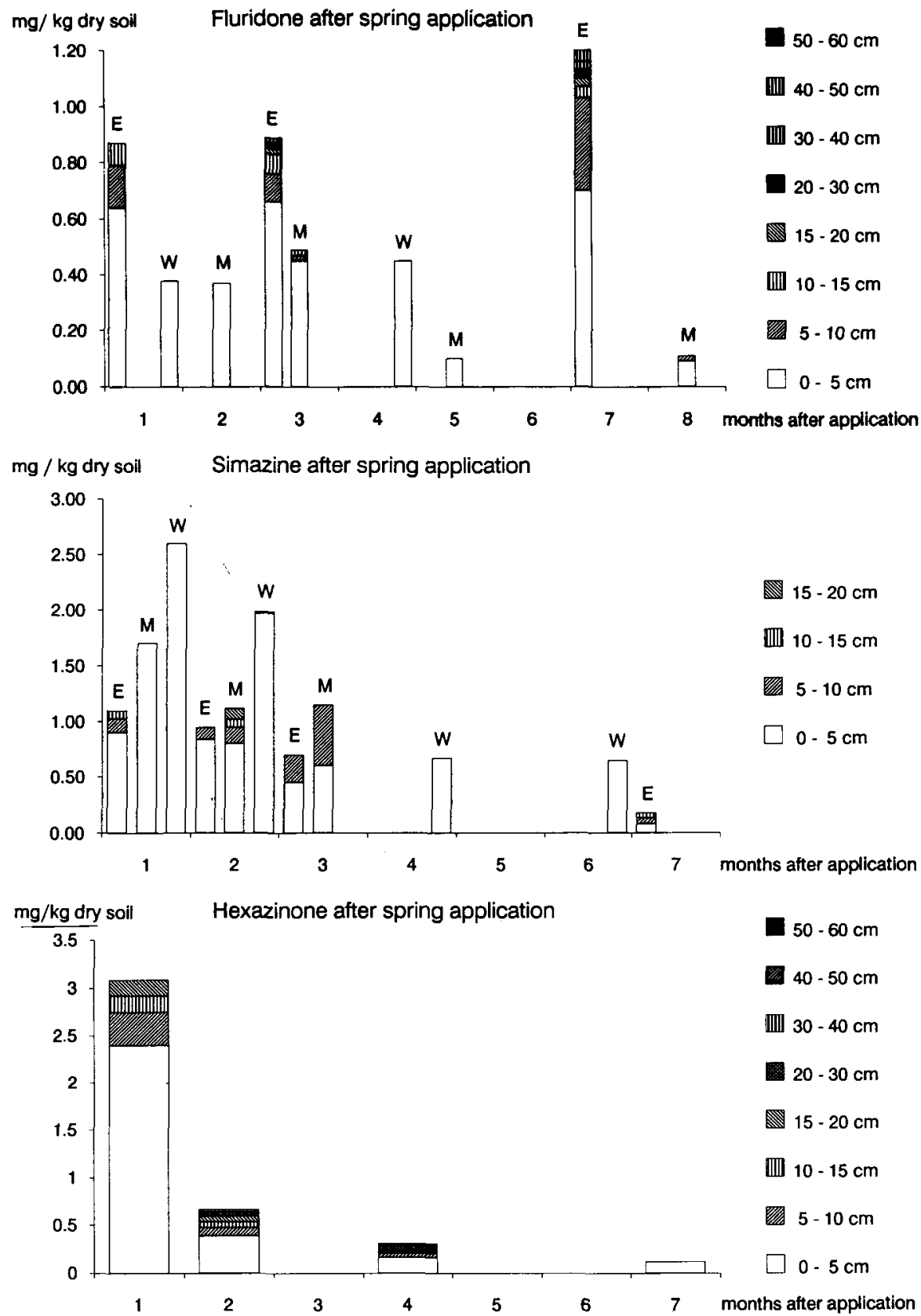

Fig. 1. Average amount of active ingredients of herbicides in different soil layers (mg kg-1 dry soil) during 8 months after spring application of fluridone in doses of $2.5 \mathrm{~kg} \mathrm{ha}^{-1}, 2.0 \mathrm{~kg} \mathrm{ha}-1$ and $2.0 \mathrm{~kg}$ $\mathrm{ha}^{-1}$ at Maarn (M), Elst (E) and Wageningen (W), respectively, and of simazine in doses of $2.5 \mathrm{~kg}$ $\mathrm{ha}^{-1}, 4.0 \mathrm{~kg} \mathrm{ha}^{-1}$ and $2 \mathrm{~kg} \mathrm{ha}^{-1}$ at Maarn, Elst and Wageningen, respectively, and of hexazinone in a dosis of $3 \mathrm{~kg} \mathrm{ha}^{-1}$ at Elst. 

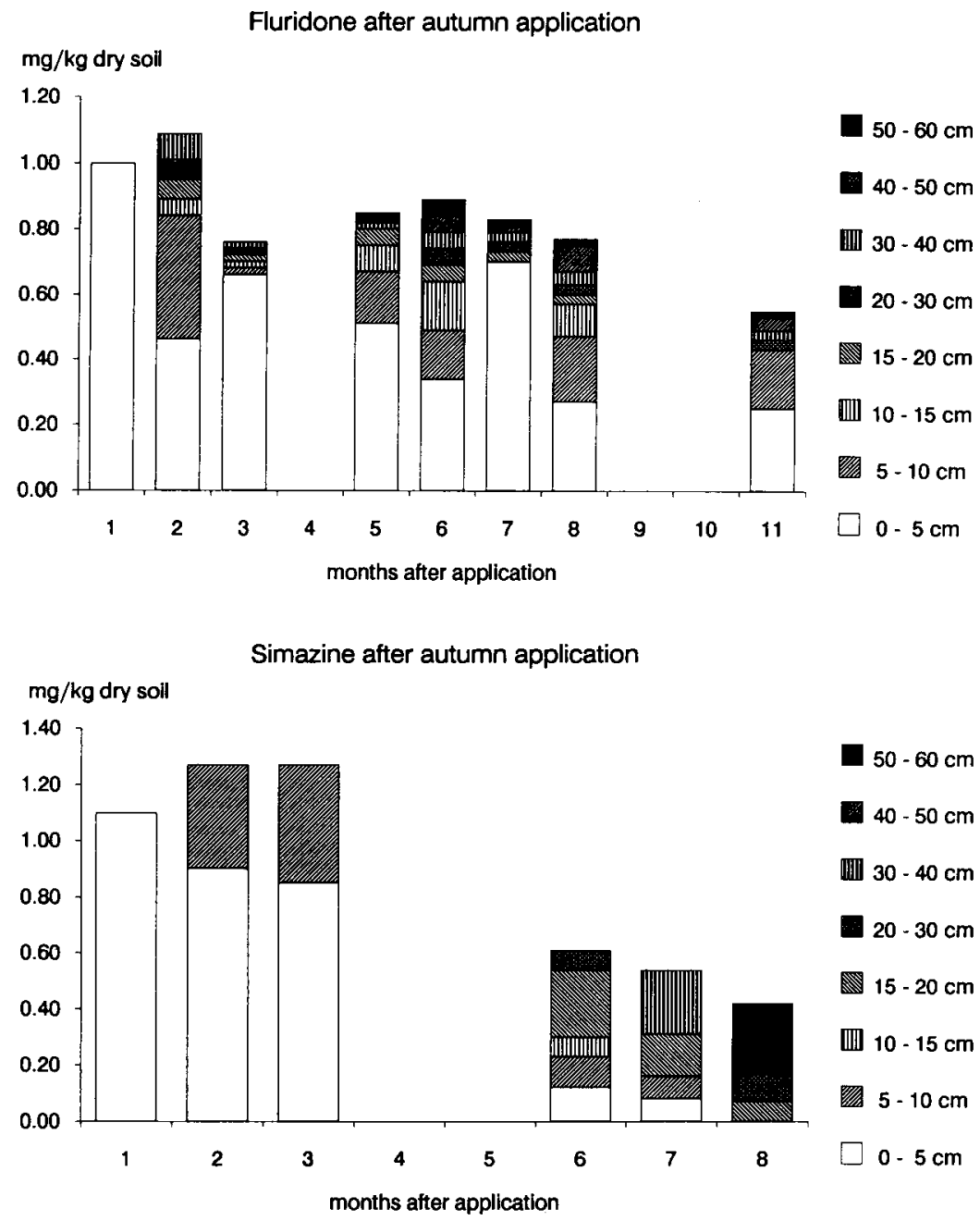

Fig. 2. Average amount of active ingredients of fluridone and simazine in different soil layers $(\mathrm{mg} \mathrm{kg-1}$ dry soil) during 8-11 months after autumn application of fluridone and simazine in a dosis of $2 \mathrm{~kg} \mathrm{ha-1}$ at Elst.

present in the next $10 \mathrm{~cm}$. Traces of fluridone penetrated to depths of $60 \mathrm{~cm}$ at Elst. The total amount of fluridone recovered at Elst decreased to $40 \%$ in 3 months and at Maarn to $3 \%$ in 8 months. At Elst that of simazine decreased to $4 \%$ of the applied dose in 6 months and at Maarn to $40 \%$ of the applied dose in 2 months. Hexazinone residues in samples from Elst were recovered mainly in the top $10 \mathrm{~cm}$ and in small quantities in samples from deeper layers. The total amount recovered decreased to $3 \%$ of the applied dose in 7 months.

After an application in autumn (Fig. 2) fluridone and simazine in a coarse sand 
were detected to a depth of $60 \mathrm{~cm}$ in the following summer. In 11 months the residue for fluridone decreased to $30 \%$ and for simazine to $30 \%$ in 7 months. The disappearance was faster in spring than in winter.

\section{Discussion}

The highest concentrations of fluridone and simazine were found in the top $10 \mathrm{~cm}$ of the soil profile at Maarn and Elst and in the upper $2 \mathrm{~cm}$ at Wageningen. As the content of organic matter was the highest in these layers, these results correspond with the results of Talbert \& Fletchall (1965) and Weber et al. (1986).

Although total rainfall was nearly the same in the first month after the spring application (about $35 \mathrm{~mm}$ ), leaching of both herbicides at Maarn was less than at Elst, due to the higher content of organic matter in the top layer at Maarn.

At Elst, fluridone and in particular simazine leached more after autumn than spring application. The rainfall in the first period after spraying in autumn was higher than after the spring application. Moreover, evaporation of a bare soil is lower in autumn than in spring and consequently the excess of rainfall over evaporation was higher in autumn than in spring. The low temperature in winter delayed degradation of fluridone and simazine in the field at Elst and thus the possibility of leaching increased. Delayed degradation was found for simazine in laboratory experiments by Walker (1976). From half-life data for hexazinone (Rhodes, 1980; Bouchard et al., 1985) and from the amounts recovered (Elst), it can be concluded that degradation can be so slow that contamination of deeper layers with hexazinone is possible even after a spring application. The data presented here and in former publications for bromacil (Zandvoort et al., 1980) show that contamination of deeper soil layers may occur on sandy soils with a low content of organic matter. To prevent leaching of herbicides it is recommended that applications be restricted to herbicides with a short to moderate persistence on sandy soils with a low content of organic matter in spring.

\section{References}

Banks, P. A., M. L. Ketchersid \& M. G. Merkle, 1979. The persistence of fluridone in various soils under field and controlled conditions. Weed Science 27: 631-633.

Bouchard, D. C. \& T. L. Lavy, 1985. Hexazinone adsorption-desorption studies with soil and organic adsorbents. Journal of Environmental Quality 14: 181-186.

Bouchard, D. C., T. L. Lavy \& E. R. Lawson, 1985. Mobility and persistence of hexazinone in a forest watershed. Journal of Environmental Quality 14: 229-233.

Rhodes, R. C., 1980. Soil studies with 14C-labeled hexazinone. Journal of Agricultural and Food Chemistry 28: 311-315.

Talbert, R. E. \& O. H. Fletchall, 1965. The adsorption of some s-triazines in soils. Weeds 13: 46-52.

Walker, A., 1976. Simulation of herbicide persistence in soil. II. Simazine and linuron in long-term experiments. Pesticide Science 7: 50-58.

Weber, J. B., P. H. Shea \& S. B. Weed, 1986. Fluridone retention and release in soils. Journal Soil Science Society of America 50: 582-588.

Zandvoort, R., D. C. van Dord, M. Leistra \& J. G. Verlaat, 1979. The decline of propyzamide in soil under field conditions in the Netherlands. Weed Research 19: 157-164. 


\section{R. ZANDVOORT}

Zandvoort, R., G. W. van den Born, J. M. Braber \& J. H. Smelt, 1980. Leaching of the herbicide bromacil after application on railroads in the Netherlands. Water, Air and Soil Pollution 13: 363-372.

Zandvoort, R. \& J. M. Braber, 1981. The persistence of some herbicides after soil fumigation with metam-sodium. Proceedings EWRS Symposium on Theory and Practice of the Use of Soil Applied Herbicides: 178-189.

This synopsis is based on a report by $R$. Zandvoort, with the same title. $C A B O$ Report Nr 75, Centre for Agrobiological Research, Wageningen, Netherlands, 1987, 14 pp., 2 figs., 8 tables, 15 refs. (English; Dutch summary). Available (free of charge) as paper copy (order R094) at: NARD, c/o Pudoc, P.O. Box 4, 6700 AA Wageningen (telex 45015 bluwg $\mathrm{nl}$ ). 